\title{
Obywatel monitorialny a rozwój nowoczesnego zaangażowania i kontroli społecznej
}

A naliza teoretyczna zjawiska partycypacji różnych podmiotów w szeroko rozumianej rzeczywistości społeczno-politycznej, a dokładniej w określonym reżimie demokratycznym, odnosi się zazwyczaj do następującej zależności: im większa sfera wolności i/lub poszanowania dla aktywności oraz praw poszczególnych podmiotów, tym większe zaangażowanie oraz udział tychże podmiotów w życiu zbiorowym. Powyższa zasada rozumiana jest tutaj jako ustawiczny proces emancypacji jednostek, grup czy warstw w danej całości społecznej przez ich praktyczne zaangażowanie w sprawy publiczne, co ma prowadzić nie tylko do marginalizacji oraz ograniczania roli państwa, lecz ma służyć przede wszystkim sprawnemu funkcjonowaniu i optymalizacji decyzyjnej w życiu zbiorowym, czyli w rożnych instytucjach, organizacjach, stowarzyszeniach itp. (tutaj sfera instytucjonalno-normatywna jest tworzona dla obywateli oraz dzięki ich uczestnictwu, przez co staje się optymalnym i pożądanym regulatorem dla systemu politycznego jako takiego). Zależność opisująca czynną postawę obywatelską jest w tym rozumieniu precyzyjnym wyjaśnieniem dla samego mechanizmu partycypacji zarówno jednostkowej, jak i zbiorowej w określonym reżimie politycznym. W ten sposób próbuje się adekwatnie scharakteryzować zjawisko czynnej współodpowiedzialności obywateli (realni uczestnicy zmian i procesów społecznych) za demokratyczny ład i porządek.

Równocześnie należy pamiętać, że postępująca rewolucja technologiczna, zwłaszcza na płaszczyźnie komunikacji społecznej, której synonimem jest rozwój Internetu (zarówno ilościowy - coraz więcej osób ko- 
rzystających z sieci, jak i jakościowy - coraz bardziej nowoczesne formy komunikacji między internautami), wymusiła nowe spojrzenia na kwestie zaangażowania publicznego i samą obywatelskość. W tym rozumieniu mamy do czynienia z nowymi praktykami odbioru, czyli z jakościowo nowymi sposobami uczestnictwa w kulturze i/lub społeczeństwie, gdzie poprzez budowanie i/lub tworzenie złożonych sieci komunikacyjnych powstaje nowy typ interakcji oraz wymiany informacji; gdzie „ewoluowała relacja pomiędzy nadawcami i odbiorcami, otwierając zapośredniczoną przez środki przekazu sferę publiczną na oddolną aktywność internautów" [Godzic 2010: 105]. Wyraźnym dowodem takiego stanu rzeczy jest tworzenie się społeczeństwa online czy też "wspólnot wirtualnych", które będąc złożonymi interakcjami internetowymi, stają się przesłanką dla nowoczesnego społeczeństwa interaktywnego [Castells 2008: 362-369]. Stąd podkreśla się, że symbolem tych wielopłaszczyznowych zmian technologiczno-komunikacyjno-społecznych jest konwergencja, która w zasadzie łączy się z takimi zjawiskami, jak: kultura uczestnictwa w warunkach ponowoczesności (to proces, w którym konsument staje się coraz bardziej widoczny, tzn. ma coraz większą siłę oddziaływania na nowo powstającą kulturę chociażby w kontekście takich narzędzi, jak: Web 2.0 nowy typ serwisu internetowego, który zmienił paradygmat interakcji pomiędzy właścicielem serwisu a jego użytkownikami na rzecz większego udziału tych ostatnich; przykładami mogą być: Wikipedia, blogi, YouTube itd.); zmiana kulturowa (to zachęcanie konsumentów do wyszukiwania nowych informacji i tworzenia połączeń pomiędzy treściami rozproszonymi w różnych środkach przekazu); cyrkulacja treści (to przepływ treści między odmiennymi platformami medialnymi); zbiorowa inteligencja (to inteligencja poszczególnych konsumentów, przy czym konsumpcja stała się procesem kolektywnym, globalnym i homogenicznym); „mit czarnej skrzynki" (to teza, że wcześniej czy później wszystkie treści medialne będą trafiać do gospodarstw domowych przez pojedynczą "czarną skrzynkę" - w tym przypadku wymiernym efektem konwergencji jest powstawanie urządzeń multimedialnych o coraz większych możliwościach łączących w sobie różne technologie, np. laptopy, iPody, GameBoy itd.) [Jenkins 2007: 7-28]. 


\section{Pojęcie obywatelskości w naukach społecznych}

W perspektywie społeczeństwa interaktywnego oraz zjawiska konwergencji punktem wyjścia do zrozumienia współczesnego zaangażowania i kontroli społecznej powinno być precyzyjne wyjaśnienie pojęcia obywatelskości w naukach społecznych. Intuicja badawcza podpowiada, że jest to termin wieloznaczny i dynamiczny w swojej formie oraz zakresie znaczeniowym. Zresztą tak jak większość terminów odnoszących się do życia społecznego, podlega on licznym interpretacjom wśród badaczy teoretyków, co w zasadzie jest bezpośrednio warunkowane modyfikacją i/lub zmianami zachodzącymi w obrębie społeczeństwa jako takiego (w obszarze stosunków społeczno-politycznych to przede wszystkim powstawanie zupełnie nowych: form organizacyjnych; struktur oraz subsystemów w zasięgu danego systemu; interakcji i sprzężeń komunikacyjnych między elementami danej całości społecznej; układów zależności i/lub nadrzędności, czyli relacji władzy itd.). Taką prawidłowość artykułuje również współczesna metodologia, w której adekwatne rozpoznanie oraz zdefiniowanie otaczającej rzeczywistości społecznej staje się zabiegiem bardzo trudnym. Zwłaszcza jeżeli jest to bezpośrednio związane z prawidłowym wyjaśnieniem pojęć dynamicznych, czyli kategorii zmiennych w rzeczywistym czasie, zarówno pod względem treści (to stosowanie różnego typu zdań o różnej wartości logicznej, na podstawie których budowana jest eksplikacja dla danego pojęcia), jak i zakresu (to ustalanie precyzyjnej definicji dla danego pojęcia na podstawie zbioru terminów, których kompilacja i wybór znaczeniowy jest dowolny) [Pawłowski 1978: 115-145]. Dlatego kategoria obywatelskości będzie rozpatrywana in concreto, tj. nie jako metapojęcie pozostające $w$ relacji semantycznej z innymi pojęciami, lecz w węższym rozumieniu jako kategoria, której treść jest precyzyjnie wyartykułowana pod kątem realnie istniejących warunków społeczno-politycznych.

W ogólnej formule obywatelskość oznacza wyznaczenie formalnego statusu podmiotu w obrębie określonego porządku państwowego. Dlatego termin ten rozpatrywany z punktu widzenia społeczeństwa jako takiego odnosi się zarówno do poszczególnych członków danej całości społecznej, jak też stanowi istotny atrybut tejże zbiorowości. W tym rozumieniu obywatelskość to: „swoisty światopogląd i dyspozycja społeczeństwa obywatelskiego, wywodząca się z uczestnictwa jednostek w jego zbiorowej świadomości [...]. Obywatelskość jest poznawczą i normatywną postawą, 
w której osobowość jednostki świadomie przyzwala na jej uczestnictwo w osobowości zbiorowej, ograniczającej oraz kształtującej jej decyzje oraz działania"1. Uszczegółowiając powyższą definicję, można wyróżnić trzy podstawowe poziomy analizy odnoszące się do pojęcia obywatelskości:

1. Poziom metaprawny - gdzie modelem wyjaśniającym jest jurydyczny ideał obywatelskości pojmowany jako rezultat powstania określonego stosunku prawnego pomiędzy jednostką, tj. obywatelem, a państwem. W tym układzie jednostka przez sam fakt przynależności do danej wspólnoty państwowej staje się jej członkiem, a co za tym idzie - jej obywatelem. Z kolei członkostwo w określonej zbiorowości tworzy podstawę do wystąpienia stosunku prawnego łączącego obywatela z państwem (taki stan rzeczy oznacza, że obywatel ma określone prawa, wolności, jak też obowiązki względem wspólnoty, które w zasadzie formalizują oraz instytucjonalizują aktywność obywatelską);

2. Poziom zbiorowej (kolektywnej) świadomości politycznej - gdzie obywatelskość jest definiowana przez pryzmat wyabstrahowanej, historycznie zmiennej oraz różnorodnej w swojej treści i formie świadomości odnoszącej się do wspólnoty rozumianej jako pewna zwarta całość (w tym przypadku jurydyczny ideał obywatelskości musi być komplementarny w stosunku do przyjętych oraz powszechnie zaakceptowanych w danym społeczeństwie zasad, norm, kodeksów, wzorców zachowań itd.). Na tym tle zostaje ukształtowana świadomość zbiorowa obywatelskości, która staje się naturalną siłą napędową dla funkcjonowania struktur oraz mechanizmów danego reżimu politycznego (dla demokratycznego porządku oznacza to, że podmiotom zostaje zagwarantowany nie tylko udział w dyskusji publicznej na temat poszczególnych wzorców

${ }^{1} \mathrm{~W}$ tym rozumieniu status obywatelski jest konstrukcją polityczno-prawną odnoszącą się do podmiotów zorganizowanych w określonym porządku państwowym. Równocześnie ma on bezpośredni wpływ na poczucie obywatelskości, czyli na trzy istotne elementy: 1. na przekonanie, iż „, coś ode mnie zależy", tzn. na zasadność siły sprawczej podmiotu w stosunku do zastanej struktury społecznej; 2 . na poczucie bezpieczeństwa wobec instytucji działających w obrębie danego reżimu politycznego (wyznaczenie pozycji oraz roli obywatela $\mathrm{w}$ danym porządku państwowym ogranicza dowolność traktowania podmiotów przez instytucje, a zwłaszcza przez instytucje władzy, i nadaje tym relacjom formę skodyfikowaną); 3. na zobowiązania podmiotów (obywateli) wobec wspólnoty politycznej, której stają się członkami. Dlatego poczucie obywatelskości jest warunkiem koniecznym pojawienia się zachowań obywatelskich, czyli świadomych działań i decyzji na rzecz dobra ogółu. Więcej na ten temat w: [Wnuk-Lipiński 2005: 101-116]. 
obywatelskich, lecz umożliwia się im również współdecydowanie o ich kształcie i znaczeniu ustrojowym);

3. Poziom indywidualnej świadomości politycznej - gdzie obywatelskość jest utożsamiona $z$ danym zespołem postaw poznawczych i normatywnych jednostki oraz korespondujących z nim wzorcem zachowań. W tym przypadku poprzez kontakt oraz interakcję z otoczeniem jednostka (obywatel) zdobywa wiedzę i doświadczenie; ujawnia swoje potrzeby, interesy, preferencje itd., przez co określa swój stosunek do zastanej zbiorowości. Sytuacja taka prowadzi do powstania układu orientacji przestrzennej pomiędzy konkretną wspólnotą a jej obywatelem, w którym kształtuje się hierarchia celów oraz wartości zarówno samej jednostki, jak też zbiorowości, do której ona przynależy (proces kształtowania się specyficznej struktury postaw i opinii na temat dobra i/lub interesu indywidualnego oraz dobra i/lub interesu ogółu). Na tej podstawie można dopiero mówić o wzbudzeniu w jednostce świadomości przynależności do wspólnoty politycznej oraz do poczucia lojalności wobec wygenerowanej przez tę zbiorowość sfery normatywno-instytucjonalnej (tutaj pojęcie obywatelskości wyjaśniane jest każdorazowo przez pryzmat jednostkowej postawy i zaangażowania wobec wspólnoty)².

Poprzez wyodrębnienie płaszczyzn wyjaśniania dla kategorii obywatelskości widzimy, że w ogólnej formule termin ten oprócz tego, iż oznacza wyznaczenie formalnego statusu podmiotu w obrębie porządku państwowego jest w swojej istocie określany w dwojaki sposób (to określenie pozycji, czyli wielostopniowy proces świadomej identyfikacji obywateli w relacji do zbiorowości):

1. W odniesieniu do zbiorowości jako takiej - gdzie zarówno pojedynczy, jak i zbiorowy podmiot buduje swoją obywatelskość, czyli pewien określony typ zaangażowania oraz postawy w stosunku do spraw publicz-

2 Pojęcie obywatelskości w najbardziej ogólnym znaczeniu jest definiowane jako: „zespół etyczno-moralnych, prawnych, intelektualnych, społecznych i mentalno-kulturowych predyspozycji i zachowań człowieka jako obywatela, ukształtowanych na podłożu jego podmiotowego statusu prawnego". Stąd obywatelskość w kontekście teorii demokratycznej jawi się jako: „rezultat wielostopniowego procesu świadomego samookreślenia się jednostek bądź grup jako obywateli, cechuje się ona względnie stabilnym i trwałym, chociaż nie w pełni niezależnym od wpływu czynników sytuacyjnych (zwłaszcza w warstwie emocjonalno-efektywnej i ewaluatywnej) systemem wzorców normatywnych (zasad, wartości, ocen, samoidentyfikacji itd.) oraz dyspozycji do zachowania się (nastawienie wobec przedmiotu postawy)". Więcej w: [Bokajło, Dziubka 2001: 85-128]. 
nych, na podstawie warunków zewnętrznych. Tutaj aktywnośćformułuje się dzięki socjalizacji ogólnospołecznych norm, kodeksów itd., tzn. poprzez postawę konformistyczną, czyli ukierunkowaną adaptację wzorca postaw obywatelskich zbieżnych z prawnie określonym systemem normatywnym. Przykładem zaakceptowania zewnętrznego wzorca aktywności obywatelskiej przez pojedynczy podmiot może być stabilne zachowanie wyborcze, w którym oprócz tego, że obywatel (wyborca) angażuje się w sprawy publiczne przez sam fakt regularnego uczestnictwa w wyborach, ma równocześnie sprecyzowane poglądy polityczne, tzn. jego głos świadczy o silnym utożsamianiu się z konkretną partią polityczną. Tutaj udział w wyborach jest rzeczywistym potwierdzeniem dla akceptacji reguł ogólnospołecznego postępowania, w którym obywatel ma świadomość, iż legitymizacja dla danego reżimu politycznego oraz wybór reprezentantów wymaga od niego dopełnienia obowiązku czynnego prawa wyborczego, nie tylko względem wspólnoty politycznej, do której należy, lecz zwłaszcza dla faktu potwierdzenia własnego statusu obywatela $w$ tejże wspólnocie. $Z$ kolei dla podmiotu zbiorowego przykładem przyjęcia zewnętrznego wzorca obywatelskości może być działalność organizacji pozarządowej, której uczestnictwo w sprawach publicznych jest warunkowane nie tylko przez zapisanie i przyjęcie jakiegoś statusu i/lub funkcji w danej zbiorowości, lecz przede wszystkim wynika z respektowania reguł formalnoprawnych porządkujących istnienie danego reżimu politycznego;

2. W odniesieniu do właściwości podmiotowych - gdzie zarówno pojedynczy, jak i zbiorowy podmiot buduje swoją obywatelskość na podstawie warunków wewnętrznych, tzn. dwóch komplementarnych procesów: a) Poczucia obywatelskości - to wrodzone i/lub nabyte cechy, które kształtują rodzaj oraz intensywność zaangażowania społecznego. Cechy te są zależne od stopnia wrażliwości i/lub responsywności na kwestie dotyczące ogółu [Etzioni 2004: 181-203]; b) Konfrontowania tego poczucia z rzeczywistą praktyką społeczno-polityczną - to proces „zderzania się” podmiotowej responsywności obywatelskiej z regułami i zasadami kierującymi określonym reżimem politycznym (tutaj to konfrontacja na styku: formalne umiejscowienie obywatelskości a wewnętrzne rozumienie uczestnictwa w sprawach publicznych przez obywatela). Przykładem obywatelskości określanej na podstawie warunków wewnętrznych dla zbiorowego podmiotu polityki może być 
działalność Pomarańczowej Alternatywy w czasach PRL-u. W tym przypadku grupa społeczna, jaką była PA pod przewodnictwem lidera (Waldemara "Majora" Frydrycha), sama próbowała definiować swoją wrażliwość społeczną. Jej poczucie obywatelskości stanowiło konglomerat luźnych inicjatyw i pomysłów, gdzie za każdym razem starano się„wyjść do obywatela, czyli zaangażować biernego uczestnika zniewalającego systemu". W tym układzie postawa obywatelskości miała przekładać się na resztę społeczeństwa, co oznaczało uczestnictwo szeroko rozumianych mas w kontestacji systemu politycznego (czynny protest oraz opór), jak też w wypracowywaniu sceptycznej postawy wobec tegoż porządku ustrojowego (bierne nieposłuszeństwo). Dlatego obywatelskość PA wiązała się przede wszystkim z alternatywnym zachowaniem oraz odmiennym sposobem myślenia w stosunku do powszechnie nakreślonej wizji i statusu „bycia obywatelem w PRL-u" [do mechanizmów obnażających absurdy PRL-u PA stosowała działalność happeningową, do której można zaliczyć takie inicjatywy, jak: używanie pomarańczowego koloru jako alternatywy dla wszechobecnej czerwonej symboliki; spontaniczne akcje uliczne, np. rozdawanie papieru toaletowego (towaru deficytowego); wykrzykiwanie i wypisywanie surrealistycznych haseł typu: „obywatelu, pomóż milicji, pobij się sam”]. Na płaszczyźnie formalnoprawnego rozumienia uczestnictwa podmiotu w życiu zbiorowym było to w zasadzie „zderzanie się" dwóch antagonistycznych wizji partycypacji: spontanicznego, oddolnego ruchu obywatelskiego (podmiot zbiorowy, czyli PA, rozumiany jest tutaj jako pewnego typu forma opozycyjności, czyli w pierwszym rzędzie próba odreagowania czasów PRL-u, jak i próba stworzenia odmiennego sposobu postrzegania rzeczywistości, w tym polityki) z systemowo zdefiniowanym, gdzie obywatel powinien utożsamiać się z funkcjonującym ładem państwowym (zjawisko uczestnictwa w tym przypadku było ściśle sformalizowane, czyli dla przykładu sprowadzało się do obowiązkowego udziału obywateli w pochodzie z okazji święta 1 Maja).

Nie możemy przy tym zapominać, że kategoria obywatelskości bardzo często odnosi się do społeczeństwa obywatelskiego. W tym znaczeniu określa się relację, jaka występuje pomiędzy obywatelem i/lub obywatelami (członkami danej wspólnoty) a państwem, czyli analizuje się publiczne postawy, cnoty, opinie oraz działania różnego typu podmiotów pod kątem ich aktywnego uczestnictwa w życiu politycznym i troski o do- 
bro wspólne (w warstwie opisowej taka postawa badawcza ukierunkowuje analizę na rozstrzygnięcia dotyczące sposobu organizacji społecznej, powstawania oraz funkcjonowania określonych instytucji, procedur itd.) [Pietrzyk-Reeves 2006: 13-31]. Równocześnie, żeby można było określić jakiekolwiek sprzężenie pomiędzy obywatelem (podmiotem) a państwem (strukturą społeczną), muszą być spełnione trzy podstawowe warunki, do których zaliczymy: 1. Istnienie aktywnych, świadomych i myślących o interesach społeczności obywateli, którzy przez swoją postawę partycypują w zbiorowości; 2 . Realne funkcjonowanie zależności politycznych opartych na zasadach równości; 3. Występowanie stosunków społecznych polegających na zaufaniu i współpracy (to brak ścisłej hierarchizacji, izolacji i nieufności w stosunkach społeczno-politycznych) [Putnam 1995: 31]. Dlatego podstawową funkcją społeczeństwa obywatelskiego jest mediacja, dzięki której możliwe jest wypracowanie kompromisu między antagonistycznymi siłami społecznymi (tutaj przestrzeń publiczna jawi się jako swobodny obszar komunikacyjny, w którym funkcjonują autonomiczne i niezależne od państwa obszary aktywności obywatelskiej)33.

W historycznej perspektywie możemy wyróżnić cztery polityczne konteksty, w których instytucjonalizowała się, a co za tym idzie rozwijała się, obywatelskość rozumiana jako rodzaj zaangażowania. Tej heurystycznej typologii odpowiadał określony wzorzec aktywności (uczestnictwa) będący wyznacznikiem powstawania relacji na styku dobro/interes ogółu (przestrzeń publiczna)-dobro/interes jednostki (przestrzeń prywatna). W przypadku warstwy odnoszącej się do zbiorowości jako takiej (public space) można określić następujące rodzaje obywatelskości:

1. Rewolucyjna (wynikająca z kontekstu rewolucyjnego) - obywatelskość jest kombinacją pragnień i żądań wysuwanych w stronę suwerena.

${ }^{3}$ Z pewnością do funkcji społeczeństwa obywatelskiego zaliczymy takie, jak: 1. artykulacyjna - agregowanie rozproszonych na poziomie mikrostrukturalnym dążeń, celów, interesów, potrzeb i wartości w większe całości i reprezentowanie ich zarówno wobec struktur państwa, jak i wobec opinii publicznej; 2. integracyjna - skupianie wokół zagregowanych i upublicznionych celów, interesów, dążeń i wartości zwolenników i mobilizowanie ich do uczestnictwa w zorganizowanych formach zbiorowego działania w sferze publicznej bądź chociażby mobilizowanie do poparcia dla określonej organizacji lub stowarzyszenia; 3. edukacyjna - wykształcenie wśród swoich członków postaw i cnót obywatelskich, mobilizowanie demokratycznych reguł gry (procedur) regulujących aktywność w przestrzeni publicznej lub nawyku uczestnictwa w życiu publicznym (to poprawa kultury politycznej wśród członków danego społeczeństwa). Więcej w: [Wnuk-Lipiński 2005: 117-139]. 
W tym przypadku obywatele (członkowie danego porządku państwowego) kontestują, podważają i zwalczają dany reżim polityczny przez aktywne, często siłowe, uzewnętrznienie swoich pragnień, potrzeb, emocji, interesów itd. W ten sposób kładzie się nacisk na sferę publiczną, która pod wpływem walki rewolucyjnej ma stać się pożądanym ładem społecznym (często taka rewolucyjna postawa może przeistoczyć demokratyczne prawa w publiczny terror);

2. Pasywna demokracja - obywatelskość sprowadza się tutaj do jednorazowego aktu wyborczego, kiedy to obywatel oddaje głos na swojego reprezentanta, by później wykazywać bierną postawę wobec legitymizowanego przez siebie porządku państwowego (tylko w momencie oddania głosu werbalizuje się sfera prywatna obywatela). Tutaj obywatel staje się pasywnym uczestnikiem procesów społecznych. Równocześnie brak zaangażowania obywatelskiego tłumaczy się demokratycznymi instytucjami, procedurami czy regulacjami, które poprzez swoją sprawność, równoważenie nastrojów społecznych oraz kompromisowe wypracowywanie skutecznych rozwiązań dla bieżących konfliktów społecznych nie prowadzą do wyzwolenia w obywatelu żadnej energii sprawczej (zgodnie z prawidłowością: jeżeli procedury demokratyczne zabezpieczają i chronią w granicach prawa wolności obywatelskie, to po co aktywnie uczestniczyć w życiu publicznym).

Natomiast dla przestrzeni odnoszącej się do jednostki jako takiej (private space) obywatelskość przejawia się $\mathrm{w}$ dwóch typach warunków politycznych:

3. Liberalny pluralizm - obywatelskość jest rozumiana zarówno jako indywidualny układ orientacji (to realizacja jednostkowych potrzeb, aspiracji, wartości itd.), jak i odczytywana jest przez artykulację zbiorowych interesów określonych grup czy ruchów społecznych. To położenie nacisku na wielość i różnorodność praktyki społecznej, dzięki której możliwe jest urzeczywistnienie się wielorakich postaw zaangażowania obywateli w życie publiczne;

4. Plebiscytowy autorytaryzm - obywatelskość przedstawia się tutaj jako stan okresowy, tzn. rząd centralnie zarządza sferą publiczną i zaprasza członków danej wspólnoty politycznej okresowo do wyborów, a obywatele po dokonaniu aktu wyboru swoich reprezentantów nie są już nigdy pociągani do odpowiedzialności za ten wybór (to zjawisko marginalizacji obywateli) [Turner 1990: 189-217]. 


\section{Obywatelskość a współczesne teorie demokratyczne}

Pomimo licznych interpretacji opisujących i wyjaśniających fenomen zaangażowania obywateli w życie publiczne, a co za tym idzie - odnoszących się do realnego funkcjonowania społeczeństwa obywatelskiego, należy zauważyć, że gros współczesnych analiz teoretycznych jest konstruowana na jednym warunku brzegowym, tj. na ściśle określonej predyspozycji obywatela. W tym układzie jest to analiza antropocentryczna, w której podstawowa teza zakłada, iż istnienie społeczeństwa jako całości jest warunkowane (poprzedzone) istnieniem aktywnych, świadomych i myślących o interesach społeczności obywateli, którzy przez swoje zaangażowanie i dbałość o dobro wspólne partycypują w danej zbiorowości. Stąd badacze teoretycy utożsamiają bardzo często kategorię obywatelskości z określonym reżimem politycznym, tj. z systemem demokratycznym. Taka sytuacja wynika w zasadzie z praktyki liberalno-demokratycznej, w której istota funkcjonowania określonej zbiorowości, a co za tym idzie - relacja na styku państwo-obywatel z założenia sprowadzała się do: emancypacji (to usunięcie możliwie wszystkich praktycznych przeszkód na drodze do szeroko rozumianej wolności jednostkowej, czyli likwidacja różnego typu form władzy nieopartych na rozumie i przyzwoleniu); przejrzystości (to postrzeganie społeczeństwa jako sumy jednostek, czyli całość społeczna jest tylko agregatem, sumą swoich elementów. W tym rozumieniu państwo jest niczym innym niż przedstawicielem społeczeństwa odpowiedzialnym za wykonywanie nieodzownych minimalnych funkcji publicznych); harmonii (to stan, w którym za sprawą różnych mechanizmów, na przykład kontroli społecznej, konflikty zagrażające przejrzystości są łagodzone bez stwarzania niebezpieczeństwa dla zdobyczy emancypacji) [Hoffmann 2005: 85-106]. Dodatkowo podkreśla się, że obywatelskość rozumiana jako wyraz określonej postawy jednostki wobec ogółu ma dopełniający charakter w stosunku do reżimu demokratycznego, w ktorym jest on postrzegany jako pluralistyczny konglomerat preferencji, działań, wartości, celów itd. różnych podmiotów (to dynamiczna przestrzeń społeczna, w obrębie której występuje niezliczona sieć powiązań komunikacyjnych, które generowane są przez jednostki, małe i/lub wielkie grupy społeczne). Dlatego, chcąc w pełni wyjaśnić obywatelskość w praktyce de- 
mokratycznej, odwołano się do dwóch modeli teoretycznych: agregatywnego i deliberatywnego.

W odniesieniu do koncepcji agregatywnych podkreśla się, że demokracja powinna skupić się wokół racjonalnie rozpoznawalnego dobra wspólnego [to teza wywodząca się od Jana J. Rousseau, który podkreślał, iż w wyniku procedur podejmowania decyzji powinna ujawniać się wola powszechna, która odzwierciedla dobro wspólne (funkcja społecznego dobrobytu)]. Dlatego w kontekście legitymizacji danego reżimu społeczno-politycznego, a dokładniej w trakcie realizacji procesu decyzyjnego odnoszącego się do tego porządku, należy przyjąć regułę większościową ${ }^{4}$. Oznacza to sytuację, w której proces ten powinien w prosty sposób agregować preferencje obywateli, które to z kolei wyrażane są w wyborach bezpośrednich. Praktyka społeczna jest traktowana tutaj jako zbiór danych preferencji, gdzie w wyniku dyfuzji wielopoziomowej, z jednej strony, kumulują się interesy, potrzeby itd. danych obywateli, co może zaowocować przyjęciem pewnego kompromisu, z drugiej zaś strony - występuje pomiędzy nimi walka oraz współzawodnictwo. Jest to zgodne z twierdzeniem:

Jednostki (obywatele) mają zróżnicowane preferencje w stosunku do instytucji rządowych. Zdają sobie również sprawę, że inne jednostki mają takie preferencje niekoniecznie podobne. Demokracja jest więc procesem, w którym partie polityczne oraz kandydaci oferują to, co przyciąga preferencje największej liczby jednostek. Obywatele z podobnymi preferencjami często organizują grupy interesu po to, aby wpływać na działania partii oraz wybranych polityków. Jednostki, grupy interesów i funkcjonariusze publiczni myślą strategicznie, przystosowując swoje orientacje i cele (np. zawieranie koalicji) zgodnie z ich rozumieniem preferencji wyborców [Farrelly 2004: 137-150].

Również teorie deliberatywne poszukują dobra wspólnego, lecz z tym zastrzeżeniem, że odnajdą je nie poprzez agregację preferencji, ale

${ }^{4}$ Teorie agregatywnej demokracji podkreślają, że reguła większościowa sprzyja współzawodnictwu idei, co przyczynia się do politycznej stabilizacji przez sam fakt instytucjonalizowania się nieustannej możliwości obalenia status quo. Równocześnie przeciwnicy tych koncepcji twierdzą, iż tak pojmowana demokracja może prowadzić do tyranii większości, ale także do tyranii strategicznie umiejscowionej mniejszości, czy też tyranii nieracjonalnej przypadkowości. Więcej w: [Shapiro 2006: 13-28]. 
raczej poprzez ich transformację [Shapiro 2006: 28-46]. Zwolennicy tego podejścia kładą nacisk na wzmocnienie demokracji przez zwiększenie partycypacji obywateli w życiu politycznym, co oznacza podejmowanie racjonalnej dyskusji, czy też publicznej debaty na rzecz wypracowania zbiorowego porozumienia. W najbardziej ogólnej definicji demokracja deliberatywna oznacza odwołanie się do: „idei, zgodnie z którą usankcjonowane prawodawstwo wynika z publicznej deliberacji obywateli. Jako normatywne uzasadnienie legitymizacji, demokracja deliberatywna przywołuje ideał racjonalnego prawodawstwa, partycypacyjnej polityki oraz samorządności obywatelskiej. Krótko mówiąc, prezentuje ona ideał politycznej autonomii opartej na praktycznym rozumowaniu obywateli" [Bohman, Rehg 1997: 3-33]. W takim układzie celem deliberacji jest ograniczanie różnic opinii, a co za tym idzie - dążenie do takiego politycznego rozumowania, które wszystkim członkom danego porządku politycznego wydaje się uzasadnione. Stąd legitymizacja wszelkich procesów decyzyjnych jest definiowana jako wiążąca wtedy, gdy odnosi się do danej zbiorowości, czyli powinna dać się uzasadnić, jeśli jest to tylko możliwe wobec każdego, kto będzie tymi procesami związany (tutaj deliberacja, rozumiana jako proces wypracowywania decyzji odnoszących się do całości społecznej, wymaga co najmniej trzech elementów: elementarnej kompetencji obywatela - uczestnika deliberacji; sformułowania własnego stanowiska i/lub opinii przez obywatela; obywatelskiej debaty, podczas której wszystkie propozycje mają szanse w równym stopniu zostać zaprezentowane, poparte argumentami i przedyskutowane $)^{5}$.

${ }^{5}$ Na tej podstawie można mówić o kilku podstawowych cechach demokracji deliberatywnej: 1. Jest trwałym i niezależnym związkiem, którego członkowie spodziewają się, że będzie on istniał do bliżej nieokreślonej przyszłości; 2. Jest to związek, w którym członkowie podzielają zobowiązanie do koordynowania swej aktywności w ramach instytucji czyniących deliberację możliwą, zgodnie z normami ustalanymi podczas wspólnych rozważań; 3. Jest to związek pluralistyczny, w którym członkowie mają różne preferencje, przekonania, idee itd. odnoszące się do przebiegu ich własnego życia; 4. To związek, w którym procedury deliberatywne są źródłem legitymizacji; 5 . Członkowie debaty postrzegają się wzajemnie jako posiadający zdolności deliberatywne, tzn. zdolności potrzebne do wzięcia udziału w publicznej wymianie argumentów. Więcej na ten temat w: [Juchacz 2006: 15-82]. 


\section{Obywatelskość w dobie nowych mediów}

Nie możemy przy tym zapomnieć, że współczesne uczestnictwo obywateli w sferze publicznej odnosi się w coraz większym stopniu do nowoczesnej partycypacji (participatory culture), w której Internet staje się swego rodzaju rdzeniem i/lub siłą sprawczą „publicznej przestrzeni komunikacyjnej". W tym układzie pojedyncze akty komunikacyjne internautów tworzą złożony obszar przepływów, w którym dochodzi do efektywnej, niezapośredniczonej interakcji pomiędzy użytkownikami sieci. Oznacza to sytuację, w której: „sfera publiczna opiera się na koncepcji opisującej ją w kategoriach nie tyle technologii, co przestrzeni mediacyjnej i zmediatyzowanej" [Lister et al. 2009: 328-332]. Stąd Internet staje się narzędziem zaangażowania, dzięki któremu może: „uczestniczyć każdy, kto ma dostęp do komputera, modemu i usług internetowych, co daje nową władzę licznym jednostkom i grupom, które w erze Wielkich Mediów były wykluczone z demokratycznego dialogu" [Kellner 2001: 6]. W takiej perspektywie obywatelskość jest definiowana na poziomie nowoczesnej komunikacji społecznej, a dokładniej na podstawie zjawiska konwergencji, które jest utożsamiane z powstaniem nowych mediów (to zacieranie się barier pomiędzy komunikacją publiczną a prywatną). W tym rozumieniu konwergencja dotyczy takich obszarów, jak: urządzenia końcowe (tutaj to łączenie różnych urządzeń w jedno urządzenie, np. odtwarzacze MP3, terminale przenośne Bluetooth itd.); rozwiązania (tutaj to ujednolicanie metod dostępu do sieci i usług); sieć (tutaj to ujednolicanie rozwiązań sieciowych, które służą do realizacji różnych usług) [Białobłocki et al. 2006: 131-133]. Równocześnie konwergencja prowadzi do stopniowej integracji sieci komunikacji elektronicznej (to przełamywanie barier instytucjonalnych oraz technicznych) pomiędzy odrębnymi dotąd sektorami tychże mediów, tj. między prasą, radiem, telewizją, Internetem itd. Konsekwencją takich zmian jest powstanie syntetycznego modelu komunikowania, który nie tylko jest wypadkową obecnych modeli (interpersonalnego, grupowego, masowego) oraz cech komunikacji sieciowej, ale również prowadzi do cyfryzacji mediów. Poza tym zjawisko cyfryzacji przekształca wszystkie media elektroniczne w interaktywną, wielofunkcyjną multiplatformę zdolną połączyć komunikację masową z indywidualną. Dlatego uważa się, że konwergentna cyfrowa komunikacja elektroniczna nabiera zupełnie nowych jakościowo cech, które w jasny sposób odróżniają ją od tradycyjnego radia czy telewizji. Do jej 
wyróżników można zaliczyć między innymi: interaktywność i multimedialność (to wymienność ról pomiędzy nadawcą i odbiorcą); asynchroniczność (przekaz może być zmagazynowany i odebrany w dowolnym momencie); indywidualizację i/lub personalizację (nadawca może adresować swój przekaz do dowolnej jednostki czy grupy; odbiorca może selekcjonować odbierany przekaz) ${ }^{6}$.

Należy przy tym dopowiedzieć, że nowe media są właściwie podłożem rozwoju kultury konwergencji, która zasadniczo wpływa na postawę, zachowanie i/lub uczestnictwo jednostek w życiu zbiorowym. W tym ujęciu kultura konwergencji, będąc złożoną gamą znaków, symboli, obrazów itd., funkcjonuje jako „imperium znaków". Stąd zdaniem niektórych badaczy taki stan rzeczy jest niepożądaną, wręcz instrumentalną technokulturą, która działa na zasadzie: „budowania zgody poprzez manipulację symbolami”. Jedyną sensowną przeciwwagą dla takiego „imperium znaków” jest jamming kultury, czyli mechanizm zagłuszania kultury poprzez "hakowanie mediów", „wojnę informacyjną", „terror-art" czy "semiotyczną partyzantkę”. Postawa taka ma na celu „boksowanie się z cieniami"; przeszkadzanie tym, którzy w sposób bezpardonowy narzucają całemu społeczeństwu określone reguły konsumpcji, interpretacji, estetyki, mody, stylu życia itd. Dlatego jammerzy, z założenia, mają nadawać medialnym artefaktom nowe, wywrotowe znaczenia; mają dekomponować dyskurs publiczny tak, by rozszyfrowywać i/lub pozbawić uwodzicielskiej siły medialnych monopolistów, co w prostej linii oznacza świadome zaangażowanie [Dery 2004].

\section{Obywatel monitorialny, czyli zaangażowanie i kontrola w dobie nowych mediów}

Chcąc lepiej uchwycić istotę zmiany zachodzącej na styku obywatel-sfera publiczna,MichaelSchudsonzaproponowałkoncepcjęobywatelamonito-

${ }^{6}$ Za prototyp konwergentnej cyfrowej komunikacji uznaje się Internet, który dzięki standardowi Internet Protocol (IP) jest w stanie przekazywać wszystkie elementy usług multimedialnych, tj. tekst, obraz, video i dźwięk. Internet jest tutaj symbolem konwergencji, ponieważ przełamuje tradycyjne rozumienie mediów przez fakt, że umożliwia jednoczesną komunikację porozumiewawczą (one-to-one), rozsiewczą (one-to-many) oraz powszechną (many-to-many). Więcej na ten temat w: [Jakubowicz 2008: 74-75]. 
rialnego (monitorial citizen). Autor zauważył, że w dobie cywilizacji Web 2.0 poprzez sam fakt dostępu do komputera, a co za tym idzie przeglądania stron internetowych, obywatele mogą praktycznie znaleźć wszystkie informacje na temat danej rzeczywistości politycznej, tzn. polityków, ich biografii czy życia osobistego itd. Stąd obywatelstwo pojmowane jako faktyczne zaangażowanie $w$ tradycyjnym rozumieniu poszczególnych obywateli w sferę publiczną jest obecnie może mniej intensywne, co nie znaczy, że mniej wartościowe. Ma ono nadal istotny wpływ na życie polityków (kandydatów), zwłaszcza na ich codzienne życie, co przejawia się tym, iż „ilość informacji, którą możemy zdobyć na temat polityka w danej chwili, jest ograniczona tylko wymiarami monitora" [Schudson 2004: 49-59]. Równocześnie Michael Schudson zauważył, że większość komentatorów politycznych funkcjonuje w kulturze progresywnej i popełnia błąd fałszywego rozumowania progresywnego (the Progressivist fallacy), tzn. że bycie dobrym obywatelem oznacza bycie dobrze poinformowanym. Według autora to tylko jedna strona medalu, ponieważ demokracja jest osadzona na silnych obywatelach, partiach politycznych, prawie i wcale nie opiera się tylko i wyłącznie na zasadzie informacyjnego centrum. Przy czym potencjał ery komputerów leży oczywiście w dostępie do informacji, lecz należy przy tym pamiętać, że Internet nie usuwa istniejących struktur społeczno-politycznych, ale daje jedynie narzędzia agregacji informacji, możliwość nowych połączeń z wyborcami (newsletter) itd. [Schudson 2004: 49-59]. Jak zauważyli David Merritt oraz Maxwell McCombs, w modelu opisanym przez Schudsona obywatele wiedzą wystarczająco dużo, by uczestniczyć (partycypować) w życiu społeczno-politycznym. Przy czym obywatele monitorialni w porównaniu z obywatelami poinformowanymi raczej skanują informacje, niż je czytają ze zrozumieniem. W tym ujęciu obywatele monitorialni nie gromadzą informacji, nie identyfikują się z nimi, lecz śledzą je uważnie, nie wgłębiając się za bardzo w treść. Dopiero gdy napotykają jakąś kluczową z ich punktu widzenia informację, łączą się w określoną sieć i następuje ich faktyczna partycypacja [Merritt, McCombs 2004: 29].

W tym rozumieniu możemy powiedzieć, że obywatele monitorialni cechują się:

1) znajomością nowych technologii, zwłaszcza tych związanych z Web 2.0 oraz z szukaniem, przetwarzaniem, kreowaniem itd. informacji w serwisach internetowych; 
2) przekonaniem, że rozkwit nowoczesnych technologii sprzyja oddolnej komunikacji i/lub e-mobilizacji (przykładami takiego oddolnego zaangażowania mogą być między innymi: bunt polskich internautów przeciw rządowi, który chciał wprowadzić rejestr zakazanych stron, wyrażony założeniem portalu podziękujpremierowi. pl; e-mobilizacja młodych Polaków przed wyborami parlamentarnymi w 2007 roku wyrażona akcją „zabierz babci dowód”; inicjatywa podjęta kilka lat temu przez władze Dystryktu Columbia AppsForDemocracy, która zaowocowała kilkudziesięcioma serwisami opracowanymi przez aktywnych obywateli, którzy wykorzystywali otwarty dostęp do danych publicznych);

3) krytyczną analizą informacyjną, czyli analizą opartą na skanowaniu informacji, a nie ich dokładnym zrozumieniu, gromadzeniu itd., co pozwala "kontrolować" w sposób powierzchowny większą liczbę danych, a co za tym idzie - koncentrować się tylko na takich informacjach, które są ważne i/lub istotne z punktu widzenia danego obywatela, grupy internautów, wydarzenia politycznego itd.;

4) specyficznym typem zaangażowania, które ma swoje źródła najczęściej w świecie wirtualnym (przyczynami partycypacji obywateli w tym układzie mogą być: niezadowolenie wyrażone na jakimś forum internetowym; sieciowa reakcja na jakieś wydarzenie, konflikt, informację itd. ze świata realnego), a skutki widoczne są w świecie rzeczywistym (przeprowadzanie akcji protestacyjnych, strajków, happeningów itd.).

Na podstawie wyżej wymienionych cech wydaje się, że koncepcja obywatela monitorialnego ery Web 2.0 podkreśla, iż współczesna władza nie koncentruje się tylko na szeroko pojętej informacji (zgodnie z tezą, że informacja równa się władza), lecz związana jest z krytycznym oraz selektywnym procesem skanowania tychże informacji. Równocześnie jedynie poprzez świadomą kontrolę może nastąpić faktyczne zaangażowanie, które oprócz tego, iż de facto mobilizuje osoby dotąd nieuczestniczące w życiu zbiorowym, staje się skutecznym narzędziem wpływu na sferę publiczną. 


\section{Bibliografia}

Białobłocki Tomasz, Moroz Janusz, Konopka Nowina Maria, Zacher Lech W. 2006. Społeczeństwo informacyjne. Istota. Rozwój. Wyzwania. Warszawa: Wydawnictwa Akademickie i Profesjonalne.

Bohman James, Rehg William (red.). 1997. Deliberative Democracy. Essays on Reason and Politics. Cambridge: MIT Press.

Bokajło Wiesław, Dziubka Kazimierz. 2001. Społeczeństwo obywatelskie. Wrocław: Wydawnictwo Uniwersytetu Wrocławskiego.

Castells Manuel. 2008. Społeczeństwo sieci. Warszawa: Wydawnictwo Naukowe PWN.

Etzioni Amitai. 2004. Wspólnota responsywna: perspektywa komunitariańska. [w:]

P. Śpiewak (red.). Komunitarianie. Wybór tekstów. Warszawa: Fundacja Aletheia.

Farrelly Colin. 2004. An Introduction to Contemporary Political Theory. Londyn: Sage Publications.

Godzic Wiesław (red.). 2010. Media audiowizualne. Podręcznik akademicki. Warszawa: Wydawnictwa Akademickie i Profesjonalne.

Hoffmann Stanley. 2005. Kilka uwag o teorii i praktyce demokratycznej. [w:] P. Śpiewak (red.). Przyszłość demokracji. Wybór tekstów. Warszawa: Wydawnictwo Aletheia.

Jakubowicz Karol. 2008. Polityka medialna a media elektroniczne. Warszawa: Wydawnictwa Akademickie i Profesjonalne.

Jenkins Henry. 2007. Kultura konwergencji. Zderzenie starych i nowych mediów. Warszawa: Wydawnictwa Akademickie i Profesjonalne.

Juchacz Paweł W. 2006. Deliberacja - demokracja - partycypacja. Szkice z teorii demokracji ateńskiej i współczesnej. Poznań: Wydawnictwo Naukowe Instytutu Filozofii UAM.

Lister Martin, Dover Jon, Giddings Seth, Grant lain, Kelly Kieran. 2009. Nowe media. Wprowadzenie. Kraków: Wydawnictwo Uniwersytetu Jagiellońskiego.

Merritt David, McCombs Maxwell. 2004. The Two W's of Journalism: The Why and What of Public Affairs Reporting. Mahwah: Lawrence Erlbaum Associates, Inc. Publishers.

Pawłowski Tadeusz. 1978. Tworzenie pojęć i definiowanie w naukach humanistycznych. Warszawa: Państwowe Wydawnictwo Naukowe.

Pietrzyk-Reeves Dorota. 2006. Współczesny kształt idei społeczeństwa obywatelskiego. [w:] B. Krauz-Mozer, P. Borowiec (red.). Czas społeczeństwa obywatelskiego. Między teoriq a praktyką. Kraków: Wydawnictwo Uniwersytetu Jagiellońskiego. 
Putnam Robert D. 1995. Demokracja w działaniu. Tradycje obywatelskie we współczesnych Włoszech. Kraków: Fundacja im. Stefana Batorego.

Schudson Michael. 2004. Click Here for Democracy: A History and Critique of an Information - Based Model of Citizenship. [w:] H. Jenkins, D. Thorburn (red.). Democracy and New Media. Cambridge: MIT Press.

Shapiro lan. 2006. Stan teorii demokracji. Warszawa: Wydawnictwo Naukowe PWN.

Turner Bryan S. 1990. Outline of a Theory of Citizenship. „Sociology” vol. 24, no. 2.

Wnuk-Lipiński Edmund. 2005. Socjologia życia publicznego. Warszawa: Wydawnictwo Naukowe Scholar.

\section{Źródła internetowe}

Kellner Douglas. 2001. Techno-politics, new technologies, and the new public spheres. „Illuminations". http://www.uta./edu/huma/iluminations/kell32.htm.

Kowalski K. 2007. Szara strefa, czyli starcie reklamy i sztuki.„Bunkier.art.pl”, nr 1 (1), 17.09. http://teksty.bunkier.art.pl/?id=5, 27.08.2010. 